in that country. For the greater part the development of co-operation in countries like Germany and Holland has been the result of the activity of one or two strong personalities who were the leaders of an idealistic movement. Co-operation in Europe has been one of the means - and a very important one - to raise the standard of living and to bring more justice. For the underdeveloped countries it may even be more. There is in Burma as far as I can see a kind of vacuum in an idealistic respect and a sound co-operative movement may offer possibilities to fill this gap. Much depends on the influence of the real leaders of the nation and much depends too on the real strength of the co-ops themselves.

The bottle-necks are manifold and what is needed most is education. Education in three directions :

1 to make people conscious of what co-operation can be;

2 to use co-op as a practical lesson in selfhelp and in democracy;

3 to learn people to accept small sacrifices to-day in order to get larger advantages to-morrow.

\title{
LiteratuRE
}

Colin Clark, The world's capacity to feed and clothe itself, "The way ahead", Vol. II no. 2.

\section{AGRICULTURE AND TECHNICAL ASSISTANCE IN PAKISTAN ${ }^{1}$ )}

\author{
Ir. G. C. W. CHR. TERGAST
}

As agricultural economist $I$ have been for fourteen and a half months in Pakistan on an assignment of F.A.O.'s Expanded Technical Assistance Program. During this period I visited several parts of the rural areas, conferred with many authorities of the central and provincial governments, private persons and several international experts of various agencies on technical assistance assignments in Pakistan, all directly or indirectly working on agriculture and its connected problems. All this gave me an excellent opportunity to study Pakistan's agricultural development and to understand its needs and requirements.

Agriculture in Pakistan has large opportunities for further development, but under the existing circumstances and conditions there are several hampering factors which will take much time to overcome, when realizing the possibilities in a short couple of years.

Before going into these problems in some more detail I will try to give in a short survey an idea about Pakistan of today with its agriculture and the many problems connected.

Pakistan got its independency on August 14, 1947. On that date the former British Indian subcontinent was divided into two independent countries : 1 . the Dominion of Pakistan including those regions with a majority of Moslim population, and 2. the Republic of India, called Bharat by Pakistani, where

1) Received for publication May 24, 1953. 
the majority of the population follow the Brahman religion. This partition of a country that for ages had been administered as one unity created many troubles and tanglements which were difficult to solve. In the beginning much bloodshed was the result, especially in the Punjab where in some weeks time from both sides together some 700.000 persons were massacred. This was followed by the migration of millions of people from one country to the other under very difficult circumstances, a phenomenon which is still not yet ended. Furthermore several established relations were torn apart, as in the jute industry, where the processing plants were situated in Calcutta and came to belong to India, while $80 \%$ of the jute producing areas, and in fact the best ones went to Pakistan, immediately creating huge difficulties for both countries.

India's attitude against some Moslim rulers who chose to join the Dominion of Pakistan like those of Junagadh and Manavadar, or who wanted to stay independent like the Nizam of Hyderabad, was not in favour to establish better understanding. Ultimately the Kashmir problem resulted in a clash between the two countries which by intervenience of the United Nations was changed in an armistice, that up till now has not ended in peace and still requires from both countries heavy expenses on defence, while it gives fuel to prolonged embitterment.

Out of the some 4 million square kilometres of former British India less than one million became Pakistan with about 76 millions of population out of the former total of 420 millions for the whole subcontinent.

Pakistan is a country devided into two parts with more than 1200 miles Indian territory between them, which also created administrative and economic difficulties.

West-Pakistan covering some 923.000 sq.km. with 33.5 million people consists of the provinces Punjab, N.W. Frontier, Sind and Baluchistan, several States of which Bahawalpur, Khairpur and Kalat are the most important, while, moreover, many tribal areas belong to it. West-Pakistan must be classed with the semi-arid area of the Near-East. Large parts have a desertlike climate : 5 to 8 inches of yearly rainfall in southern Baluchistan, Sind and the southern half of Punjab, 10 to 20 inches in the other parts, mostly falling in the months of July-August; the summers are hot with maxima of over $125^{\circ} \mathrm{F}$, while the hot period extends from April till October; the winters are mild in the south, but can be cold in the northern regions where night frosts occur frequently in December-February. Sind, Khairpur, Bahawalpur and Punjab where over 25 millions of people are living consist mostly of a vast uniform and very flat alluvial plain along the eastern bank of the Himalayan river Indus; some smaller plains are found on its western bank and in a part of N.W. Frontier Province. In the other parts of West-Pakistan mostly barren and eroded mountains prevail. The vast flat plain from Karachi to the Kashmir border rises gradually for only 150 to 200 feet over some 700 miles; it is some 150 miles wide in southern Sind, narrows down to 50-60 miles in southern Bahawalpur and broadens to some 200 miles in Punjab. The silt from Indus and its tributaries Jhelum, Chenab, Ravi and Sutley has built this plain and is rather fertile.

East-Pakistan covering only some 54.000 sq.km carries 42.5 million people, amongst them still some 8 millions of Hindus. It forms one province named East-Bengal. Although it lies on both sides of the Tropic of Cancer it must be counted fully to the tropics as it has an average yearly rainfall of over 
80 inches, lower in the west and higher in the east and south. The rainy season everywhere is uniform from the end of May till mid-October; the other months are very dry and almost no rainfall is noted in December-March. The temperature ranges from some $105^{\circ} \mathrm{F}$ in summer to $45^{\circ}$ in winter; the atmosphere is humid, especially in summer. Only east of Chittagong the country consists of sandy hills and some mountains, and also in southern Sylhet some low lateritic hills are found. For the rest East-Bengal is a flat deltaic plain built by the rather fertile silt of three huge rivers, Ganges, Brahmaputra and Meghna, in the south swampy with tidal forests and rising till about 100 feet in the north. The first two rivers are fed by glacier waters from both sides of the Himalaya, whereas the Meghna is getting its water from an area with heavy summer rains (North of Sylhet in the Garo Hills on Indian territory the rainfall station Cherapunji notes a yearly rainfall of 480 inches!). South of Rangpur, East of Mymensingh and East of Comilla some areas of older alluvial soil are rising a little above the surrounding plains. The three rivers are still meandering, and in May they rise quickly some 20 feet, flooding about one third of the country; in October the levels go down again.

In the British time most of the provinces and states of the subcontinent were already strongly organised on a rather autonomous base. This has not been changed by the establishment of the Dominion of Pakistan. A Federal Government, situated in Karachi, which town with some hundreds square miles became a federal district, was constituted with as main tasks : defence, foreign affairs and finance. Of course, it was understood that also in other fields of administration some parts had to be centralized, but still large parts remained under the authority of the provincial and state's governments. This leads to the fact that provinces and states have a rather important say in several fields of the daily life, and this does result in different attitudes to and handling of common problems, giving cause to undesirable frictions. Luckily in the last two years more understanding has arisen as a result of the need to solve difficult problems which affected the country as a whole.

It may be mentioned here that agriculture is still mostly a provincial affair: A central Ministry of Food and Agriculture was established with a very limited task: some active supervision of agriculture in Baluchistan when it was still an agency directly under the Governor-General, but now this has been changed as Baluchistan has got the provincial status; and further some coordinating work regarding procurement and distribution of some main foodgrains (wheat, rice), plant protection (locusts), livestock diseases (rinderpest), compilation of provincial agricultural statistics, and the contacts on international level (F.A.O., Point 4). However, in the last two years its coordinating function has strengthened considerably when the provinces were faced by difficult problems which could only be solved by countrywide action: after four years with rather constant surplusses of some hundred thousand tons of food grains, Pakistan was confronted with a shortage of 400.000 tons in the seasonal year 1952-53; more or less at the same moment it saw stocks of its main export products, cotton and jute, rapidly piling up as world demand went down and prices decreased sharply.

Regarding the governmental tasks it may also be mentioned here that Pakistan had to overcome many difficulties in shortage of staff personnel, office quarters and even office equipment. As formerly most of the higher official 
posts were held by Hindus who left after the partition, many unqualified officers had to take over. Moreover, it had to struggle with the huge refugee problem, the rupture of many economic ties and the need to erect a large defence force. With all this in mind the young dominion has managed rather well in the five years of its existence.

This is the more remarkable as there is no uniformity in the origin of its population. In this respect there are easily feasable differences between the Bengali in East-Pakistan, the Punjabi of central West-Pakistan, the Pathans in the north and the Sindis in the south, the primitive nomads in Baluchistan, the Bhudist population of the Chittagong Hill Tracts and the many different tribes along the border with Afghanistan. It is the Muslim religion and its resistance against the formerly overpowering Hindus that has cemented all these groups together. Up till now they are mostly united in one political party, the Muslim League, but in the last years some splitting has occured on the left (more or less socialistic) and the right wings (orthodox muslims), internal friction between the groups being notable sometimes.

The average yearly increase of the population on the whole must be in the vicinity of $1.5 \%$; exact figures for the last years or for the different groups were not available.

In West-Pakistan about $84 \%$ of the population is rural, in East-Pakistan about $95 \%$. But in the last years the urban population is increasing rapidly: Karachi from 200.000 before the last world war to 1.2 million; Lahore from some 400.000 to over 1.000 .000 ; Lyallpur from about 200.000 to 600.000 ; Dacca from some 80.000 to 400.000 .

Illiteracy is widespread, about $85 \%$ of Pakistan's population can read nor write. Huge projects to combat illiteracy are drawn up, but the execution is still very slow. In my opinion this problem is fundamental for any speeding up of development, also for development in the agricultural field. When farmers can read and write they will be more easily reachable for extension, and the working resorts of the extension workers can be broadened considerably.

The only figure I found regarding the differentiation in cultivators and agricultural labourers amongst the rural population was in a survey on undevided Bengal in 1941, where $29 \%$ were labourers. In West-Pakistan, probably, this number will be smaller.

Pakistan is strongly an agrarian country and will remain such for decades to come. Up till now coal, iron and other minerals are only found in very small quantities, not sufficient to establish basic industries of any importance. Industrialization, strongly stimulated in the last years, is mainly possible with agricultural products as raw material. For the time being also transport, marketing and commerce can only be based on the agricultural output of the country.

Development of cotton and jute processing plants, sugar-factories, paperfactories, oil-factories, fruit-canning industries, leather tanning plants etc. is in progress.

The main export-products of the country are jute, tea and fish from EastPakistan, cotton, some wheat and rice, wool, hides and leather from West Pakistan. Jute and cotton, however, are the main products for international trade.

In West-Pakistan wheat is the main food grain, but considerable quantities of rice, maize, millets, pulses and oilseeds are also consumed; meat, fish and 
especially milk and butter are contributing to the protein and fat of the diet; also fruits are consumed in rather large amounts.

In East-Pakistan rice is the main food grain, other foodstuffs like pulses and oilseeds being consumed in much smaller quantities than in West-Pakistan. Fish is here the main source for protein, while milk and fruits are consumed to some quantities.

The average diet for the whole country calculated by F.A.O. for the seasonal year 1948-49 shows in calories 2028 units, in grams 22.5 of fats and 53.9 of protein (of which 12.7 grams from animal origin). This is better than in India and many other countries of Southeast Asia, or Africa and the tropics of the Americas.

Illustrative for the economic situation in Pakistan are the data on national and per capita income published by the U.N.O. in "National and per capita incomes of seventry countries in 1949 expressed in U.S. dollars" (Statistical papers, Series E, No. 1). The calculated per capita income for Pakistan amounts to 51 U.S. $\$$ and belongs to the lowest ones of the seventy countries mentioned. Indonesia with 25 , China 27 \$, Burma 36 , Philippines $44 \$$, are still lower, but India with 57 \$, Ceylon 67 \$, Egypt 100 \$, Brazil 112 \$, Mexico $121 \$$ are higher, while the western countries are higher still : Italy 235 , France 482 \$, the Netherlands 500 \$, United Kingdom 773 \$, U.S.A. 1453 \$.

Before going into some more details of agriculture and its main problems which have different patterns in the two parts of the country, partly as a result of the different natural conditions, first I may explain something about the problem of land tenure and the size of farm units.

As in many countries of the Near-East and South and East Asia large landownerships frequently occur here. Properties of several thousands of acres are no exception, and there are several landlords who own hundredthousands of acres and more. The undesirable feature of absentee-landlords is well known. It is sometimes said that the British rule has caused this landlordism as former landrevenue collectors have subsequently become the landlords of today. I am, however, not so sure that this was the real background everywhere in the subcontinent. Perhaps it has happened along that line in Bengal, but I think that in many other parts the British accepted existing feodal situations.

Until recently it was common that the landlords rented their lands in small units to tenants who on the average had to pay $50 \%$ of the produces.

The average unit in East-Bengal now is about 3 to 4.5 ácres. In WestPakistan it differs from province to province and according to crops, but ranges from 3 to 4 acres in Baluchistan to 6 to 12 acres in the other provinces. Even in the Punjab where, by establishing irrigation, colonization was based on blocs of 25 acres, each bloc intended for one farmer and one farmhand and their families, nowadays these blocs are normally divided into 4 units cultivated mostly by tenants.

When Pakistan was established the progressive part of the Muslim League asked for land reforms: the real cultivators of the land should become the landowners. Soon several provincies introduced some form of protection of tenants against arbitrariness of the landlords by law. Meanwhile, the problem was studied by the centre and was discussed on conferences and in periodicals.

East-Bengal was the first province that changed the land tenure system completely in 1951 by abolishing large landownerships. Since then individual 
properties are limited to 33 acres, or 150 acres for a family-property. Surplus acreages will be redistributed amongst the former tenants to become their property; a certain regulation of payments was fixed. This decision was not too difficult here as most of the former Hindu landowners had migrated to India and although refugee properties have to be administered no payments between India and Pakistan in this field have ever been done till now.

The Punjab followed with a different regulation. Landownerships were not broken up, but the area to be exploited directly by the landlord himself was limited at 50 acres irrigated land or 100 acres unirrigated land. Surplus properties have to be rented to tenants under strict conditions excluding arbitrariness from landlords. The share or rent to be paid by tenants was diminished to $40 \%$ of the production.

Also N.W. Frontier Province took new steps in 1952, but only to strengthen the rights of tenants. When I left Pakistan in September 1952 a more or less similar regulation was in discussion for Sind and Baluchistan. From the states nothing definite was heard in this field.

Connected to land tenure is the problem of fragmentation. Islamic hereditary law making this problem difficult to solve. Here too the more progressive part in the Muslim League is convinced that this law must be modified so that economic units can be maintained, but the more orthodox part is not in favour of such modification. However, in the Punjab some consolidation of properties slowly is in progress under the cooperative movement.

Climatic conditions in West-Pakistan called for irrigation to make agriculture possible on a large scale. Nowadays large areas are under irrigation in Punjab, Sind, Bahawalpur and Khairpur and smaller areas in N.W. Frontier Province and Baluchistan. New irrigation schemes are under construction, like the Thal Dessert project and the lower Sind Barrage, while several others are projected.

In connection with irrigation in this semi-arid country a menacing problem has developed. Over large areas the groundwater level has come up near to the surface creating waterlogging and salination of the soil. Pakistan has asked F.A.O. for technical assistance to help solving this problem as already 2.5 million acres are out of production, while this area is increasing every year with 20.000 to 25.000 acres. Pilotschemes are under execution now to try to find a practical solution. The problem, however, is very difficult as most of the irrigation canals are not lined and therefore seepage in the rather light soils occurs, and no drainage system was provided for. Moreover, there are indications that the water from several rivers used for irrigation carry already rather high percentages of salt.

In East-Pakistan only about $2 \%$ of the cultivated area got some primitive irrigation, but the rainfall during six months makes it possible to cultivate rice on a large scale. Cultivation during the dry season is limited to those areas where moisture in the soil is available; this is possible in about $30 \%$ of the total cultivated area. It is already mentioned that about one third of the country is affected by floods during the rainy season; in these areas it is frequently possible to cultivate long stem paddy or floating rice, but, of course, with some risk that strong floods may cause damages. The long stem paddy is an interesting plant: there are examples where stems of 30 feet long occur; the growth accompanies the rise of the waterlevel and can get a maximum speed of 3 inches per day; when submerged by one foot of water it can still reach 
the air without succumbing; furthermore this kind of rice has a good production on the average and the rice is of good quality.

The main export crop in East Pakistan is also a waterloving plant, the jute, although a type is known that can grow without submerging of the fields.

Table 1 gives a survey of the total areas, population, cultivated and irrigated areas and current fallows.

Table 1. Areas, total and cultivated, and population.

Pakistan.

\begin{tabular}{|c|c|c|c|c|c|c|}
\hline $\begin{array}{c}\text { Provinces } \\
\text { and/or States }\end{array}$ & $\begin{array}{l}\text { Total } \\
\text { area sq } \\
\text { miles }\end{array}$ & $\begin{array}{c}\text { Population } \\
\times \quad \begin{array}{l}1000 \\
3\end{array}\end{array}$ & $\begin{array}{l}\% \\
\text { rural } \\
4\end{array}$ & $\begin{array}{c}\text { Total net- } \\
\text { sown area } \\
1951-1952 \\
\times 1000 \\
\text { acres } 5 \text { ) }\end{array}$ & $\begin{array}{c}\text { Irrigated } \\
\text { area } \\
\times \quad 1000 \\
\text { acres } 6 \text { ) }\end{array}$ & $\begin{array}{c}\text { Current } \\
\text { fallow } \\
\times \quad 1000 \\
\text { acres } 7 \text { ) }\end{array}$ \\
\hline $\begin{array}{l}\left.\text { Baluchistan }{ }^{1}\right) \ldots \\
\left.\text { N.W. Frontier }{ }^{1}\right) \ldots \\
\text { Punjab ........ } \\
\text { Sind } 2 \text { ) } \ldots \ldots \ldots \\
\text { Bahawalpur } \ldots \ldots \\
\text { Khairpur . . . . . }\end{array}$ & $\begin{array}{r}134.002 \\
39.249 \\
61.989 \\
48.136 \\
17.494 \\
6.050\end{array}$ & $\begin{array}{r}1.178 \\
5.699 \\
18.814 \\
5.737 \\
1.820 \\
320\end{array}$ & $\begin{array}{l}80 \\
82 \\
85 \\
80 \\
90 \\
92\end{array}$ & $\begin{array}{r}507 \\
2.235 \\
14.414 \\
4.935 \\
2.008 \\
344\end{array}$ & $\begin{array}{r}570 \\
1.100 \\
12.000 \\
4.900 \\
1.400 \\
200\end{array}$ & $\begin{array}{l}\text { n.a. } \\
600 \\
2.600 \\
5.000 \\
\text { n.a. } \\
\text { n.a. }\end{array}$ \\
\hline $\begin{array}{l}\text { West-Pakistan } \ldots . \\
\text { East-Pakistan } \\
\text { (East-Bengal) }\end{array}$ & $\begin{array}{r}306.920 \\
54.015\end{array}$ & $\begin{array}{l}33.568 \\
42.119\end{array}$ & $\begin{array}{l}84 \\
95\end{array}$ & $\begin{array}{l}24.443 \\
23.464\end{array}$ & $\begin{array}{r}20.170 \\
200\end{array}$ & $\begin{array}{l}8.200 \\
2.600\end{array}$ \\
\hline Total Pakistan ... & 360.935 & 75.687 & 90 & 47.907 & 20.370 & 10.800 \\
\hline
\end{tabular}

1) Including states.

2) Including federal area of Karachi : population 1.118.000.

3) Census 1951 (preliminary).

4) Source: Agriculture, Pakistan, Vol. I (1949), No. 1 \& 2. (Min. Food \& Agric.).

5) Directorate of Statistics, Ministry of Food \& Agriculture.

6) Source : Confidential Report on Land Reforms by K.B. Mian Abdul Aziz (Min. Food \& Agric.) ; revised according to current changes.

7) Average of different sources.

Of course the differences in natural conditions are of influence on the choice of crops and on the cultivation methods. A separate table gives a survey on the principal crops. (Table 2).

There are also differences in livestock; in both areas cattle raising is primary, but in West-Pakistan also horses, goats and sheep are rather important, followed by buffalos, camels and poultry, while in East-Pakistan especially buffalos are important; horses, goats and sheep are secondary, no camels are raised, and next to poultry also ducks have some significance. Cattle in both parts are important for agricultural operations, but also for the production of dairy products, to which also the buffalos and goats contribute. But agriculture does not profit of the production of manure as this mainly is used for fuel in the households.

Regarding the use of agricultural equipment it may be mentioned that in general these are rather primitive and simple. The common plough, for instance, has not been changed since thousand years and over; it consists of a simple pointed piece of wood of some 3 to 4 inches thick.

A rather common feature of agriculture in both parts of Pakistan is the 
Table 2. Net-sown acreages of principal crops in 1951-1952 in thousands of acres.

Pakistan.

\begin{tabular}{|c|c|c|c|c|c|c|c|c|c|}
\hline & 苞 & 疍苞 & 㥶 & 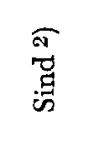 & 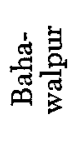 & 岂 & 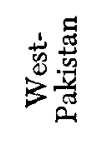 & 若 & 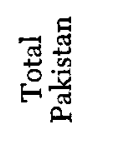 \\
\hline Rice & 67 & 37 & 766 & 1.249 & 44 & 17 & 2.180 & 20.301 & 22.481 \\
\hline Wheat . & 256 & 1.040 & 7.231 & 1.018 & 705 & 89 & 10.339 & 96 & 10.435 \\
\hline Bajra (Millet) & 5 & 90 & 1.051 & 741 & 130 & 3 & 2.020 & 1 & 2.021 \\
\hline Iowar (Sorghum) & 79 & 60 & 418 & 311 & 141 & 66 & 1.075 & 1 & 1.076 \\
\hline Maiz & 10 & 508 & 403 & 6 & 20 & - & 947 & 10 & 957 \\
\hline Barley & 9 & 153 & 255 & 15 & 16 & 2 & 450 & 82 & 532 \\
\hline a (Pulse) & 19 & 137 & 1.520 & 362 & 151 & 16 & 2.205 & 201 & 2.406 \\
\hline Rape \& Mustard & 62 & 89 & 538 & 371 & 217 & 76 & 1.353 & 502 & 1.855 \\
\hline num $\ldots \ldots$ & - & 2 & 27 & 13 & 10 & - & 52 & 144 & 196 \\
\hline ed $\ldots .$. & - & - & 7 & $=$ & - & - & 7 & 61 & 68 \\
\hline Sugarcane .... & - & 103 & 333 & 15 & 43 & 2 & 496 & 229 & 725 \\
\hline Cotton $\ldots \ldots$ & - & 16 & 1.865 & 834 & 531 & 73 & 3.319 & 57 & 3.376 \\
\hline Jute $\ldots \ldots \ldots$ & - & - & - & - & - & - & - & 1.779 & 1.779 \\
\hline
\end{tabular}

1) Including states.

2) Including federal area of Karachi.

fact that, on the whole, acreage yield of crops range among the lower ones in the world.

Table 3 gives a survey of the per acre yields of the principal crops during the last four seasonal years in comparison to average F.A.O. statistical data regarding total Asia and the world.

Table 3. Per acre yields of principal crops.

Pakistan.

\begin{tabular}{|c|c|c|c|c|c|c|c|c|}
\hline & \multicolumn{5}{|c|}{ In lbs per acre } & \multirow{2}{*}{$\begin{array}{c}\text { Con- } \\
\text { verted } \\
\text { in } 100 \mathrm{~kg} \\
\text { per ha }\end{array}$} & \multicolumn{2}{|c|}{$\begin{array}{c}\text { F.A.O. average } \\
1946-1949 \text { in } \\
100 \mathrm{~kg} \text { per ha }\end{array}$} \\
\hline & $\begin{array}{l}1948- \\
1949\end{array}$ & $\begin{array}{l}1949- \\
1950\end{array}$ & $\begin{array}{l}1950- \\
1951\end{array}$ & $\begin{array}{l}1951- \\
1952\end{array}$ & $\begin{array}{l}\text { Average } \\
4 \text { years }\end{array}$ & & Asia & World \\
\hline Rice & 876 & 837 & 819 & 772 & 826 & 9.25 & 16.75 & 16.75 \\
\hline Wheat $\ldots$. & 838 & 827 & 817 & 710 & 798 & 8.94 & 9.1 & 10.36 \\
\hline Bajra (millet) & 378 & 351 & 342 & 306 & 344 & 3.85 & 6.7 & 6.6 \\
\hline Iowar (sorghum) & 467 & 408 & 421 & 414 & 428 & 4.79 & 6.7 & 7.3 \\
\hline Maize $\quad . . . .$. & 887 & 944 & 875 & 927 & 908 & 10.17 & 10.7 & 15.9 \\
\hline Barley... & 655 & 614 & 632 & 577 & 619 & 6.93 & 10.0 & 11.1 \\
\hline Gram (pulse) . & 600 & 581 & 592 & 458 & 558 & 6.25 & - & - \\
\hline Rape \& Mustard .. & 378 & 369 & 383 & 365 & 374 & 4.19 & 5.2 & 5.4 \\
\hline Sesamum $\ldots \ldots \ldots$ & 380 & 309 & 379 & 389 & 364 & 4.08 & 3.6 & 3.75 \\
\hline Linseed ........ & 363 & 364 & 339 & 395 & 365 & 4.09 & 3.0 & 5.0 \\
\hline Gur (sugar) & 3224 & 3087 & 2797 & 2756 & 2966 & 33.22 & - & - \\
\hline Cotton (lint) .. & 146 & 174 & 168 & 156 & 161 & 1.80 & 1.45 & 2.2 \\
\hline Jute (fibre) $\ldots$ & 1168 & 854 & 1425 & 1423 & 1218 & 13.64 & 13.0 & - \\
\hline
\end{tabular}

Already since many years research resulted in obtaining higher yielding strains of several principal crops, better cultivation methods and methods to check diseases and pests, and in showing the importance of manures and fertilizers, the economic use of irrigation water, etc. When all this would be 
applied by the farmers in the right way a considerable increase of the per acre yields might be expected. To my opinion the most important hampering factor in this field is the strong conservatism amongst the illiterate farmers which only can be overcome with intensive propaganda and demonstration. The existing provincial extension services are far too small to be able to contact the majority of the farmers.

Next to intensive extension also farm credit and marketing need more close attention. Farm credit in Pakistan is organized mainly along co-operatives, but as normally only landowners are members of such co-operatives the real cultivators of the land are not able to get farm credit at a reasonable interestbase independently. Moreover, as is the case in many other Asiatic countries, the real principles of cooperation are still not very well understood in Pakistan, and the rural population cannot produce a sufficient number of leaders for this movement. Re-orientation of the co-operative movement is strongly needed, but probably education and much propaganda has to come first. As for farm credit, I think, the government has to organize a more direct system for contacting the real cultivators.

In the field of marketing all provinces have some established organisation which can be strengthened where needed according to future developments. However, related fields such as transport-, storage- and processing facilities need improvement, whereas the problem of the many groups of middlemen is a difficult one to solve under the existing circumstances.

The young Pakistan Government is convinced that one of its most important actions should be to take every possible step that may bring more welfare for the masses of its population. When since 1949 several possibilities to get technical assistance on an international level were opened Pakistan was one of first countries to ask for such assistance in many fields of its economic and social life.

In the first place it may be mentioned that Pakistan joined the Colomboplan for inter-commonwealth aid to South- and Southeast Asia. In this connection it has drawn up a six-year plan for 1951-1957 with a total expenditure of 2.600 millions of Rupees (or about 800 million U.S. \$), including 820 million Rs for agriculture, 530 million Rs on transport and communications, 470 million Rs on fuel and power, 490 million Rs for industry and mining, and 290 million Rs in the social field (housing, health, education, technical training, etc.). The plans for agriculture may be illustrated by the distribution of the 820 million Rs over the following items :

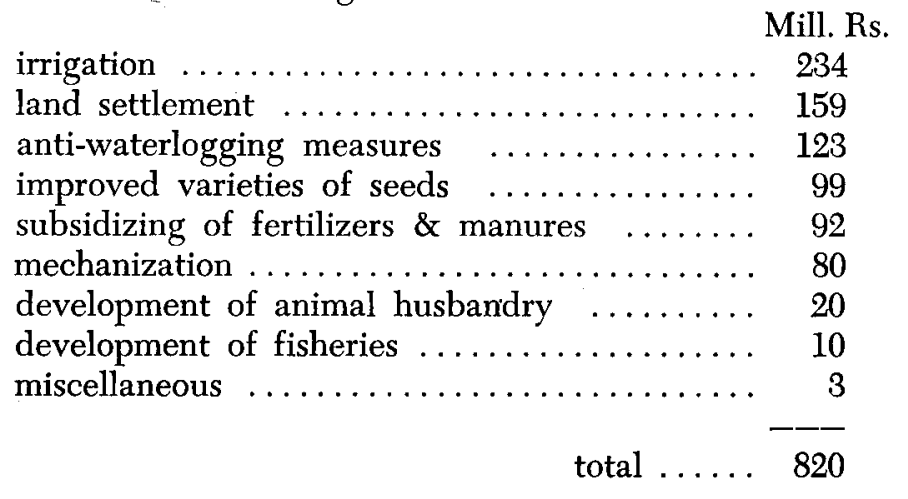


The expected results of these schemes are: an increase of the output of food grains with over 2 million tons, of which more than 500.000 tons of rice, increase of the production of oil-seeds by $220 \%$, sugarcane by $70 \%$, vegetables by $68 \%$, fruits by $90 \%$, cotton by $27 \%$ and jute by $10 \%$.

Next to these schemes of the Colombo-plan the Pakistan Agricultural Enquiry Committee, under the chairmanship of Lord BoYD-ORR and with assistance of experts of the F.A.O., has drawn up a report in which it advises actions on several very important features of agriculture: popularisation of improved seeds and new cultivation methods, mechanisation, agricultural co-operation and farm credit, improvement of statistics and the need of agricultural economic studies.

In the field of agricultural extension and rural education Pakistan has accepted expertice and help from the United State's T.C.A. (= Point 4).

Furthermore Pakistan asked for and is still getting technical assistance in many fields from the United Nations (T.A.A.) and its agencies as F.A.O., Unesco, W.H.O., I.L.O., Unicef, I.C.A.O. etc. under the Expanded Technical Assistance Program (E.T.A.P.).

The F.A.O. rendered and still renders technical assistance to Pakistan in a very wide range of activities. Several tens of agreements call for some 60 experts and some 40 fellowships. During my period on this program in Pakistan over 30 experts from F.A.O. completed their assignments (some of sinort duration but generally of one year) or were still in the field. These assignments were covering land and water development, animal diseases, agricultural economics and marketing, fisheries, forestry, agricultural statistics, slaughterhouse building, refrigeration for storage, farm mechanisation and fertilizers.

It is impossible to go into much detail about all these items, but I will explain one or two of them to give an idea on the possibilities of such technical assistance, and on some difficulties that may be encountered.

First, however, I may express my opinion regarding the development of agriculture in Pakistan and the technical assistance it is receiving. Notwithstanding the Colombo-plan, the recommendations of the Pakistan Agricultural Enquiry Committee, and the technical assistance programs of different agencies in progress, overall planning has not sufficiently been undertaken ${ }^{2}$ ). Such planning requires not only a broad list of desirabilities of actions, but also it has to take into consideration the urgency of the problems, the availability of technicians, funds and equipment to execute development plans within reasonably fixed limits of time.

A shortage of technicians which is now already felt for the existing actions in the agricultural field in Pakistan will become the bottleneck for execution of more and new development plans. The problem of how to remedy this should be studied at length, as it is in fact fundamental. For Pakistan retechnicians, the organizational establishment of groups of technical workers, and

2) In August 1953 it was announced that the Pakistan government had decided to establish a "Planning Board", consisting of a chairman and two members. This board, eventually with advisors, has to draft a national development plan for a period of five years beginning on April 1, 1954. The most profitable use has to be made of available resources and manpower. The aims are : the quickest possible development of all resources to improve welfare, creation of an adequate living standard, establishment of social services, the guarantee for social justice and a fair distribution of incomes and properties. 
orientation in this field is needed regarding the level of payment of agricultural the availability of sufficient adequate training facilities. This, however, is a complex problem that cannot be solved overnight.

Another essential problem which may hamper smooth execution of certain activities is the fact that the services which have directly or indirectly to do with agriculture are not organized along the same lines of the central government as in the provinces and states. It is necessary to find some definite form of mutual cooperation to facilitate the execution of projects of country-wide importance.

In the field of my own assignment in the beginning I encountered some difficulty to find understanding regarding my task, while later on the higher officials were so occupied by acute problems that they had almost no time to spend on the necessary consideration to new recommendations and advices. Nevertheless, I experienced the pleasure that the government of Pakistan has taken action on one of my recommendations. This concerned the necessity of a division or bureau for agricultural economics. Although my advice could not yet be followed completely on the base of the existing organizational situation and budget circumstances, a first step was done by appointing an agricultural economist in the central ministry to start agricultural economic studies.

As an example of how much internal difficulties may hamper the execution of good projects the rinderpest problem in Pakistan can be mentioned. The F.A.O.-team had drawn up a plan of immediate action for West-Pakistan to be started in the middle of 1952 , the production of vaccin was started, the needed funds and personnel were available, but internal controversy between the central government and provinces caused delay through which the right time to start the activities was missed. It is to hope that the project can be put into action this year, for it is calculated that the average loss by rinderpest amounts to several millions of rupees worth of cattle per year.

The Thal Development Project may be mentioned as a strongly organized development plan in the progress of which some good results are notable. Dating from the British period the main irrigation works were finished in 1947. The colonization in the now irrigated dessert tracts started in the end of 1949 when the first fields were prepared with machinery. Of the total of some 1.5 million acres about one third is already under cultivation. If needed, the colonists can hire machinery for net costs from the authority. This project is one of those under the Colombo-plan, but also help was given by a loan from the International Bank for Reconstruction and Development. The normal acreage per colonist is 15 acres. When visiting this area it is interesting to see how permanently irrigated agriculture can check the shifting sand dunes and turn them into good arable land.

As the end of this short survey of agriculture and technical assistance in Pakistan - a large and important problem of which I can give you only fragmentarily some main features - I will mention in short a multipurpose project for the Brahmaputra-Ganges delta in East-Pakistan made by the F.A.O.expert on waterproblems Dr W. J. van BLOMMEsTEIN, to which project I had the pleasure to contribute the preliminary economic analyses regarding the agricultural possibilities.

This project includes irrigation for large areas, some flood regulation - in total affecting nearly 15 millions of acres - the generation of hydro-electric 
power and improvements of waterways for inland navigation. The entire project is a long-term scheme that possibly will take about 30 years to be realized. However, the work can be executed in parts.

With the exception of the Surma-valley scheme, which is more or less a flood regulation scheme, all the others are irrigation schemes for the nonflooded areas of the province. In majority these areas will get gravity-irrigation, but some pump irrigation is included, as in the East-Meghna scheme and in parts of the Ganges-Kobadak and Padma-Faridpur schemes, whereas some extension in the Sylhet district will be possible. The idea is to use hydroelectric power for the pumping plants.

For the Ganges-Kobadak scheme, a part of the total scheme in the southwest corner of East-Bengal that will irrigate 2.200 .000 acres, of which scheme it is decided to start the first survey presently, the power needed partly can be generated locally, whereas the rest can be produced by a temporary thermal generation plant with wood as fuel (which can be produced from the tidalforest in South Khulna) or can be taken from the projected, and soon executed Karnafuli hydro-electric power plant. Ultimately, the total scheme includes the use of hydro-electric power for all pumping from a projected plant near Mymensingh which will generate $500.000 \mathrm{k} . \mathrm{w}$. during the rainy season, diminishing to $350.000 \mathrm{K.W}$. in the dry season. With this amount of power all projected irrigation pumping plants can be fed, the existing railroad system electrified and there will still be enough power for extending industrialization considerably.

The main canals will be made navigable for inland shipping, this being a stimulant for the development of trade in large parts of the country where hardly any highways are available.

As to the Surma-Valley scheme I may explain that there is a vast inundation basin there, where in the end of May the waterlevel rises some 20 feet in 3 weeks time. This is prohibitive even for the cultivation of long-stem paddy. This inundation lasts for some 7 months. When the water falls only small patches of land can be used for short living crops. The largest part of this area is noted as "not cultivable". The scheme will make it possible over large areas to grow one crop of long-stem paddy by regulating a three months' rise of the waterlevel before the natural inundation starts.

The capital costs of the entire multi-purpose project is estimated at 1650 millions of Pakistan Rupees (or 500 millions of U.S. dollars).

Agriculture in East-Pakistan will profit to a large extend by perennial irrigation. Where today only $30 \%$ of the cultivated area carries more than one crop a year, double cropping probably can be extended with irrigation over the entire area, whereas also triple cropping may increase considerably. Moreover, the current fallows, the cultivable waste lands and even parts of the so-called "not cultivable" areas can be turned over to yearly cultivated lands. But also the main existing crops cultivated during the rainy season will profit by irrigation, as the diminishing influences of frequent drought periods from one to three weeks in this season can be checked.

In my calculations of these possibilities for agriculture I took many precautions because statistical data were not available in much detail and not very reliable; moreover, I had to use many presumptions based on the experience of the provincial agricultural staff and my own, as exact data in many fields were lacking. In calculating the possibilities of increasing agricultural 
production I took into consideration in the first place those crops of which officially shortages are noted with a view to a desirable local diet. Along these lines the following increases of the provincial average productions were calculated : rice $20 \%$, jute $7 \%$, sugar $170 \%$, pulses $300 \%$, oil-seeds $160 \%$, wheat $140 \%$, tobacco $110 \%$. After this still some 4.5 million acres more are available for double cropping. To facilitate the calculations, the introduction of groundnuts in mixed cultivation with maize is taken into consideration: these crops are suitable as there normally will be 4 to 5 months between two main crops; they ameliorate soil conditions in rotation with rice; the maize can partly be used as green fodder; groundnuts can become a second cash crop next to jute, it improves the human diet, but also the fodder supply for live stock; besides, it can be the raw meterial for extension of the processing or industrial plants. On these bases an increase of the production of foodstuffs in East-Bengal on the whole was calculated at $67 \%$. Evaluated on the base of the price-levels of July-September 1951, the actual provincial production of crops has a value of 5400 millions of Pakistan Rupees whereas the calculated increase would be 4000 millions of Pakistan Rupees, i.e. an increase of about $75 \%$.

Notwithstanding the fact that in the thirty years which the completion of the project will take the population of East-Bengal may increase with 40 to $50 \%$, it will be clear that the national income may increase more. It must be taken into consideration that my calculations were made very conservatively, because only crop-production was taken into account. A considerable improvement of the fodder supply will result also in an increasing income from livestock; more possibilities for industrial development, transport, marketing and export will arise. In fact the realisation of the project can bring a complete change to the better in the economic aspects of this rather over-populated part of Pakistan and probably can give the incentive for further progress afterwards.

For East-Bengal it is a fortunate fact that the project can be executed in parts and that the Ganges-Kobadak scheme is chosen to be undertaken first. When this scheme can be executed in 5 or 6 years it will be possible to demonstrate the favourable possibilities of irrigation for the province within a rather short period. Then it also will give a good example of the value of technical assistance.

I may end this birdseye review of agriculture and technical assistance in Pakistan with the conclusion that this country, having accepted technical assistance of the international agencies in a broad way, may profit of the many possibilities that can be directed by this assistance. But it will be wise to select some major items to be executed first and these must be based on a thorough consideration of the availability of technicians, money and equipment. The agencies themselves can contribute to such an attitude by advising the countries which ask for technical assistance to start with an overall planning. For such planning more co-operation between the various international agencies is highly desirable. 